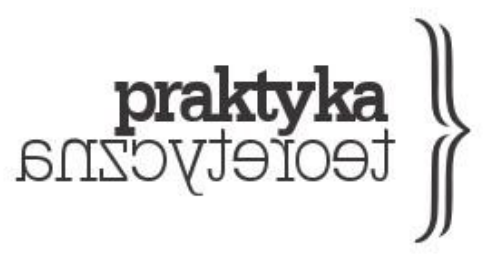

ISSN 2081-8130

DOI: $10.14746 /$ prt.2016.2.3 www.praktykateoretyczna.pl

\title{
ODKRYTA NA NOWO I UPORCZYWIE AKTUALNA - O DIALEKTYCE W FILOZOFII I POLITYCE ŚWIATOWEJ
}

\author{
KEVIN B. ANDERSON
}

\begin{abstract}
Abstrakt: Niniejszy artykuł ukazał się oryginalnie w zbiorze esejów Lenin Reloaded: Toward a Politics of Truth. Autor podejmuje w nim kwestię ewolucji poglądów politycznych i teoretycznych Włodzimierza Lenina między 1908 a 1914 rokiem, wskazując na kluczowa rolę, jaką odegrała w niej lektura Nanki logiki i studia nad Heglowską dialektyką. Andersona interesuje przede wszystkim sposób, w jaki Lenin wykorzystał nowe dialektyczne koncepty, które wywiódł z lektury niemieckiego filozofa, do sformułowania wnikliwej i radykalnej koncepcji polityki światowej. Zdaniem autora to dzięki nim Leninowi udało się w nowatorski sposób spojrzeć na kwestie kolonializmu, imperializmu i znaczenie ruchów narodowowyzwoleńczych dla polityki emancypacyjnej.
\end{abstract}

Słowakluczowe: dialektyka, ruchy narodowowyzwoleńcze, kolonializm, imperializm, odbicie/refleksja, Hegel, Lenin. 
Odwoływanie się do Lenina, nawet na lewicy, sprawia dziś wrażenie naiwności, a nawet irytuje. Od lat osiemdziesiątych dwudziestego wieku nieustannie powtarza się, że Lenin położył fundamenty pod barbarzyński system stalinowskiego totalitaryzmu i że nie tylko jego czyny, lecz również głoszone przez niego idee polityczne cechował prymitywizm, autorytaryzm, a nawet brutalność. Nieustannie usłyszeć można sugestie, że udany powrót do Marksa i marksizmu możliwy będzie tylko wtedy, gdy stworzymy „kordon sanitarny” oddzielający nas od Lenina i bolszewizmu. Imię Lenina wciąż też przywołuje się wtedy, gdy chce się pokazać wszystkim, których uwiodło „utopijne” myślenie, zgubne skutki takiego igrania z ogniem.

Chciałbym jednak dowieść, że to właśnie zwolennikom tego rodzaju twierdzeń zarzucić można naiwność i wewnętrzną sprzeczność ich argumentacji, nie mówiąc już o zwykłej arogancji. Po pierwsze, nie biorą oni pod uwagę istotnych pozytywnych osiagnięć wczesnych lat rosyjskiej rewolucji. Po drugie, nie dostrzegają oryginalnego wkładu Lenina do myśli politycznej. Po trzecie, zapominają o wielu ważnych myślicielach, wciąż zresztą powszechnie szanowanych i z aprobatą cytowanych, którzy cenili Lenina i wiele z niego czerpali. Mając to w pamięci, nie można oczywiście zapominać o potrzebie krytyki wielu aspektów życia i dorobku Lenina. Jednak przypomnienie o nich jest warunkiem wstępnym jakiejkolwiek poważnej, a nie jedynie karykaturalnej, krytyki Lenina i jego spuścizny.

Zanim zajmę się osiagnnięciami Lenina na polu teorii, chciałbym na początek podkreślić, że widzę sporo poważnych słabości, którymi obciążony jest jego dorobek intelektualny. Po pierwsze, chodzi o przyznanie wiodaccej roli partii-awangardzie. Koncepcja ta, której próżno szukać u Marksa, zbyt długo obciążała nas kiepskim modelem organizacji rewolucyjnej (zob. Dunayevskaya 1958). Po drugie, wiele z działań Lenina po 1917 roku, zwłaszcza usankcjonowanie jednopartyjności i osłabienie pozycji rad robotniczych w Rosji, nie przystaje do modelu rewolucyjnej demokracji (zob. Farber 1990). Po trzecie, chociaż dalej będę przekonywał, że Lenin miał istotny wkład w rozwój myślenia dialektycznego, to przyznać trzeba, że jego rozważania na ten temat były bardzo nierówne, co pokazuje choćby wulgarna i mechanicystyczna książka Marksizm a empiriokrytycyzm (Lenin 1984) ${ }^{1}$. Powiedziawszy to wszystko, można nadal doceniać inspirujące i atrakcyjne wątki obecne w teoretycznym dorobku tego wybitnego rewolucyjnego przywódcy. Nie trzeba przy tym identyfikować się jako „leninista”, co zresztą w dominującym dyskursie sprowadza się zwykle do przywiązania do elitarystycznej koncepcji partii-awangardy.

Zacząc chciałbym od zacytowania wypowiedzi na temat Lenina sformułowanej przez znanego myśliciela, uważanego zwykle za humanistycznego, a nawet liberalnolewicowego, który zdaniem wielu był bardzo daleki od Lenina i bolszewizmu. Mam na myśli

\footnotetext{
Poważną krytykę tej książki przeprowadził Maurice Marleau-Ponty (1973).
} 
Ericha Fromma, znanego psychologa związanego ze szkołą frankfurcką. Dla niektórych czytelników może być zaskakujące, że w późnych latach pięćdziesiątych Fromm pisał, że Lenin przesiąknięty był „bezkompromisowym poczuciem prawdy wnikającym w sama esencję rzeczywistości i nigdy nie dającym się oszukać przez zwodnicze pozory; niegasnąca odwaga i prawością głębokim oddaniem oraz troską o człowieka i jego przyszłość; bezinteresownością i [podejściem] wolnym od próżności czy pragnienia władzy”. Fromm kontrastował Lenina z „mściwym morderca” i „konserwatysta” Stalinem. Co więcej, potępiał również „powszechny nawyk traktowania stalinizmu jako [...] tożsamego z rewolucyjnym marksizmem czy jako formy jego kontynuacji”"2.

Te słowa cenionego autora, którego książki - takie jak Socjalistyczny bumanižm, Ucieczka od wolności czy O sztuce mitości - wpisuja się w nurt psychologii humanistycznej, a zarazem człowieka, który w latach sześćdziesiątych aktywnie wspierał zarówno ruchy pokojowe, jak i dysydentów z Europy Wschodniej, powinny skłaniać do namysłu. Fromm z pewnościa świadom był zarówno niszczycielskiego charakteru rosyjskiej wojny domowej z lat 1918-1921, jak i autorytaryzmu środków, po które sięgał Lenin w tym okresie. W przeciwieństwie jednak do większości osób, które dzisiaj wypowiadają się na temat Lenina i ówczesnej Rosji, Fromm dostrzegał również rozmach wizji, jaką niósł ze sobą rok 1917. Dla Fromma i sporej części jego generacji rewolucja rosyjska pomogła zakończyć bezmyślną rzeź I wojny światowej, wyniosła do władzy prorobotniczy rząd oraz wyzwoliła Żydów i inne narodowości od jarzma caratu, czyli najmniej tolerancyjnego systemu politycznego ówczesnej Europy. Rewolucja 1917 roku zainspirowała też w jego opinii wielkich rewolucjonistów, takich jak choćby Róża Luksemburg, do podjęcia próby radykalnego przekształcenia Niemiec; próby, która zakończyła się niepowodzeniem po brutalnym zamordowaniu tej autorki w 1919 roku przez prekursorów nazizmu.

\section{Lenin, Hegel i „zachodni marksizm”: przemilczane związi}

Ani uważany za lewicowca Herbert Marcuse, ani żaden inny kolega Fromma ze szkoły frankfurckiej nigdy otwarcie nie wyraził tak silnego sentymentu do Lenina, jak uczynił to autor Ucieçki od wolności. Przeciwnie, frankfurccy filozofowie wspominając o Leninie, zwykle pogardliwie określali go jako autora prymitywnego i wulgarnego (Theodor W. Adorno) lub też widzieli fundamentalną ciagłość między Leninem a Stalinem, dostrzegając w tym pierwszym prekursora późniejszego totalitaryzmu (Herbert Marcuse). Zarówno Adorno,

2 Fromm wszystkie te uwagi poczynił w niepublikowanej recenzji emigracyjnych dzienników Trockiego (Trotsky 1958). Cytowane tu fragmenty pracy dotyczyły nie tylko Lenina, lecz również samego Trockiego, a także Marksa i Engelsa (zob. Anderson 2002). 
jak i Marcuse nie powoływali się jednak nigdy na Zeszyty filozoficzne Lenina z lat 1914-1915². Wydaje się to niezwykle zaskakujące, zważywszy, jak wiele uwagi w ciagu swych akademickich karier obaj filozofowie poświęcili badaniu wzajemnych relacji marksizmu i filozofii Hegla. Jednak ich milczenie $w$ tej kwestii nie zmienia faktu, że zarówno oni sami, jak i tzw. „zachodni marksiści” lat dwudziestych - György Lukács, Antonio Gramsci i Karl Korsch - zawdzięczali Leninowi i rosyjskiej rewolucji bardzo wiele, a zwłaszcza to, że pod wpływem impulsu, jakim był 1917 rok, możliwe było ponowne odkrycie dialektycznego rdzenia marksizmu.

Tradycyjne omówienia historii „zachodniego marksizmu” i teorii krytycznej przeoczają zwykle albo w najlepszym wypadku marginalizują dwa ważne fakty. Po pierwsze, na poziomie ogólnym, że najpoważniejsza praca Lenina na temat Hegla (Zeszyyty filozoficzne) powstała w latach 1914-1915, a więc prawie dekadę wcześniej niż Historia $i$ śmiadomość klasowaLukácsa, która ukazała się w 1923 roku. Choć Leninowskie notatki na temat Hegla opublikowano po niemiecku dopiero w 1932 roku, to niektóre spośród jego tekstów na temat Hegla, pisanych po 1914 roku, opublikowano w Niemczech już we wczesnych latach dwudziestych. Tak więc Lenin pomógł torować drogę Lukácsowi.

Zachodnioniemieccy marksiści krytyczni lat sześćdziesiątych prawie nigdy o tym nie wspominali, mimo, że mieli skłonność do wychwalania Lukácsa i Korscha. Odrzucenie spuścizny Lenina dotyczyło nie tylko Jürgena Habermasa i jego uczniów, ale także tych spośród zachodnioniemieckich marksistów krytycznych, których uznaje się za znacznie bardziej lewicowych, jak choćby Oskara Negta (zob. Negt 1969). Rzadki wyjątek pod tym względem stanowi długi esej Iringa Fetschera poświęcony Heglowi i marksizmowi, opublikowany w 1960 roku, w którym pisma Lenina na temat dialektyki zostały potraktowane poważnie (Fetscher 1971; por. Anderson 1995). Jednak ten fragment rozważań Fetschera przeszedł niezauważony. Ukazanie się tego eseju nie doprowadziło do złagodzenia zajadłej krytyki Lenina prowadzonej przez Rudi'ego Dutschke i innych liderów zachodnioniemieckiej Nowej Lewicy (zob. Dutschke 1974; Rabehl 1973). Nawet berlińskie pismo Das Argument, uważane za „ortodoksyjnie” marksistowskie, miało skłonność do rozważania dorobku Róży Luksemburg, lecz już nie Lenina.

Istnieje jeszcze drugi istotny dowód przemawiający na rzecz tezy o wpływie wywartym przez Lenina na „zachodni” albo „krytyczny” marksizm. Karl Korsch, który później zdecydowanie odrzucił Leninowskie inspiracje, w książce Marksižm i filozofia (Korsch

\footnotetext{
3 Charakterystyczny jest fakt, że Marcuse w Rozumie i rewolucji, swoim przełomowym marksistowskim studium na temat Hegla i teorii społecznej, bardzo skrótowo odnosząc się do stanowiska Lenina wobec dialektyki (Marcuse 1966, 296, 379), nie wspomina nawet Zesaytón filozoficznych. W późniejszej pracy Soviet Marxism,w rozdziale o dialektyce $\mathrm{w}$ ogóle nie odnosi się do Lenina i Hegla, przedstawiając jednocześnie przejście od Lenina do Stalina jako przykład „dialektycznego prawa przechodzenia ilości w jakość” (Marcuse 1958, 74).
} 
2005) opublikowanej po raz pierwszy w 1923 roku, a więc w tym samym czasie co Historia i śniadomośc klasowa, wykorzystał jako motto słowa Lenina z 1922 roku: „powinniśmy organizować systematyczne studiowanie $-\mathrm{z}$ materialistycznego punktu widzenia - dialektyki Hegla" (Lenin 1989a, 29). Mimo to nawet tak przenikliwy filozof jak Maurice Marleau-Ponty, choć postrzegał książkę Korscha jako założycielski tekst „zachodniego marksizmu”, lokował ją w opozycji do „Leninowskiej ortodoksji” (Marleau-Ponty 1973, 64).

W przeciwieństwie do takiego stanowiska, Ernst Bloch, myśliciel współczesny Lukácsowi, Korschowi, Marcusemu i Adornowi, łączył dwudziestowieczny powrót do Hegla bezpośrednio z Leninem. Bloch twierdził, że w niemieckiej tradycji intelektualnej nie tkwiło nic, co czyniło zwrot ku Heglowi koniecznym. Jak pisał: „Hegel nigdy nie był tak zmarginalizowany, jak miało to miejsce w Niemczech po 1850 roku"4. Pod koniec dziewiętnastego i na początku dwudziestego wieku dzieła Hegla były wciąż rozważane gdzieniegdzie we Włoszech, Francji i w kręgu anglojęzycznym, jednak, jak sugeruje Bloch, rzeczywiste odrodzenie heglowskiej tradycji nastapiło dopiero po 1917 roku:

\begin{abstract}
Wstrząs pod murami Kremla był czymś więcej niż tylko echem wstrząsu, jaki zrodził lewicę heglowską. Dialektyka przestała być zapomnianym głupcem, stając się teraz żywym skandalem [...]. Jednakże to nie Hegel pozostawał wciąż w zapomnieniu, lecz raczej szykowna ignorancja oświeconego pozytywizmu. [... Lenin odnowił prawdziwy marksizm nie tylko poprzez powrót do „rdzenia” Heglowskiej dialektyki („sprzeczność jako źródło wszelkiego ruchu i życia”), lecz również poprzez sama logikę Hegla. „Nie można w pełni zrozumieć Kapitału Marksa, a zwłaszcza jego I rozdziału, jeżeli się nie przestudiowało i nie zrozumiało całej Logiki Hegla. A zatem nikt z marksistów nie zrozumiał Marksa po upływie 1/2 stulecia!!” (Lenin, Zessyty filozoficzne, s. 149). W ten sposób odświeżony przez Lenina prawdziwie ortodoksyjny marksizm, który opierał się na znajomości Hegla, stanął w opozycji do wulgarnego, schematycznego i wykorzenionego marksizmu, który - jak wystrzał z pistoletu oddzielał Marksa od Hegla, tym samym izolując się od samego Marksa (Bloch 1962, 382-383).
\end{abstract}

W podobnym duchu pisał Lukács w pierwszym rozdziale Historii i śniadomości klasowej („Czym jest marksizm ortodoksyjny?’):

Ortodoksyjny marksizm nie oznacza więc bezkrytycznego uznawania wyników badań

Marksa, nie oznacza też „wiary” w tę lub ową tezę ani nie polega na interpretowaniu

\footnotetext{
4 Jak pisał Nietzsche w eseju „Schopenhauer jako wychowawca” z 1874 roku: „dopóki rosła jeszcze na wszystkich polach piękna zielona hegelszczyzna: lecz kiedy grad wybił te zbiory, a ze wszystkich obietnic, które sobie wówczas co do niej czyniono, nie spełniło się nic i wszystkie stodoły pozostały puste" (Nietzsche 2003, 181).
} 
jakiejś „świętej” księgi. Ortodoksja w kwestiach marksizmu odnosi się raczej wyłącznie do metody. Jest nią naukowe przeświadczenie, że w dialektycznym marksizmie została znaleziona właściwa metoda badawcza, że metodę tę można kontynuować, rozwijać i pogłębiać tylko w kierunku określonym przez jej odkrywcę [...] (Lukács 1988, 68).

Te związki między Leninem a marksizmem heglowskim lat dwudziestych dwudziestego wieku zwykle pozostawały przemilczane przez badaczy zajmujacych się teorią krytyczna.

W niniejszym tekście chciałbym skoncentrować się wobec tego na trzech wątkach. Po pierwsze, na kryzysie intelektualnym, jaki przechodził Lenin w 1914 roku pod wpływem wojny i zdrady, jakiej dopuścili się socjalistyczni przywódcy. Kryzys ten zmusił go do ponownego przemyślenia wcześniej używanych kategorii. Będę starał się przekonywać, że podjęta przez niego w Zeşyytach Filozoficznych i późniejszych tekstach próba odzyskania Hegla stanowi istotny wkład w rozwój dialektycznej perspektywy marksizmu. Po drugie, sposób w jaki Lenin wykorzystał nowe dialektyczne koncepty, wywiedzione z lektury Hegla, doprowadził go do sformułowania niezwykle wnikliwej i radykalnej koncepcji polityki światowej. Szczególnie dotyczy to jego analiz kolonializmu i imperializmu z jednej strony oraz antyimperialistycznych ruchów narodowowyzwoleńczych (od Indii do Irlandii i od Chin po Środkowy Wschód) z drugiej. Po trzecie, prześledzę jak nowe spojrzenie na Hegla i dialektykę zaproponowane przez Lenina wpłynęło na późniejszych myślicieli marksistowskich. Wątki te zwykle są pomijane w pracach poświęconych Leninowi i jego myśli ${ }^{5}$, sądzę jednak, że są one niezwykle ważne dla zrozumienia tej postaci w kontekście czasów, w których przyszło jej żyć i działać. Uważam też, że pośród różnych elementów w jego teoretycznym dorobku te właśnie są dzisiaj najbardziej aktualne.

\section{Lenin, Hegel i dialektyka}

W latach dziewięćdziesiątych dziewiętnastego wieku wielu spośród najważniejszych marksistowskich intelektualistów Europy Środkowej zbliżyło się do neokantyzmu, a nawet

\footnotetext{
5 Pomimo wartościowego wkładu w innych dziedzinach ukazujące się w języku angielskim w ostatnich trzech dekadach prace na temat Lenina zwykle zupełnie ignoruja albo minimalizuja znaczenie Zeszytów filozoficznych. Czterotomowa praca Tony'ego Cliffa, zatytułowana Lenin (Cliff 1975; 1976; 1978; 1979), poświęca im jedno zdanie. Dwutomowa książka Lenin'sPoliticalThoughtNeila Hardinga $(1978 ; 1981)$ nie wspomina o nich w ogóle, natomiast trzytomowa książka Roberta Service'aLenin: Political Life (Service 1985; 1991; 1996) zajmuje się nimi co prawda na kilku stronach, choć zarazem podkreśla, że ich znaczenie było przecenianie. Późniejsza książka LeninismHardinga (1996) poświęca cały rozdział filozofii Lenina, lecz nawet Zesayty kwalifikuje jako „dogmatyczne”. Nowsza biografia Service’a (2003) stanowi w istocie krok wstecz jeśli chodzi o badania nad stosunkiem Lenina do Hegla, ponieważ poświęca tyle samo uwagi notatkom Lenina o Arystotelesie, co jego pismom na temat Hegla. Tego rodzaju wstrzemięźliwości w podejmowaniu problemu stosunku Lenina do myśli Heglowskiej nie da się natomiast zauważyć w recepcji francuskiej. We Francji, od czasu rozważań Lefebvre’a z lat trzydziestych (zajmę się nimi dalej w niniejszym artykule) nie można było ignorować istotnego długu, jaki Lenin zaciagnął u Hegla (zob. Liebman 1975; Löwy 1973). Kwestią pism Althussera zajmę się w dalszej części.
} 
do pozytywizmu. Żaden z nich, wliczając w to również Engelsa, zdawał się nie być zainteresowany Heglem. Wobec tego, gdy nadeszła sześćdziesiąta rocznica śmierci filozofa, to Rosjanin Gieorgij Plechanow napisał dla DieNeueZeit- najważniejszego wówczas na świecie pisma marksistowskiego - artykuł poświęcony pamięci twórcy nowoczesnej dialektyki. Niestety Plechanow ukuł na potrzeby tego artykułu podejrzanie brzmiące pojęcie „materializm dialektyczny”, rozwijając jednocześnie w swym eseju ewolucjonistyczną i prymitywnie materialistyczną interpretację dialektyki. Plechanow nie widział w nim żadnej poważniejszej różnicy między Marksowską dialektyką a Darwinowskim ewolucjonizmem, choć przecież w pierwszym tomie Kapitału Marks zwraca uwage na „słabe strony abstrakcyjnego materializmu przyrodoznawstwa, który nie uwzględnia procesu historycznego" (Marks 1951, 400).

Przed 1914 rokiem w kwestiach filozoficznych (w znacznie mniejszym stopniu w kwestiach politycznych) Lenin podążał tropem Plechanowa. Świetnie widać to choćby na przykładzie mechanistycznej wizji zawartej w pracy Materializm a empiriokrytycyzm. Z dwóch powodów książka ta daleka była od prawdziwie dialektycznej perspektywy. Po pierwsze, wywód Lenina opierał się na schematycznej „teorii odbicia”, zgodnie z którą marksistowski materializm uważany jest „za odbitkę, za przybliżoną kopię obiektywnej realności” (Lenin 1984, 256). Po drugie, Lenin zdecydowanie odrzucał w niej wszystkie formy idealizmu jako „jedynie zamaskowaną, upiększoną opowieść o upiorach” (Lenin 1984, 173).

Prześledźmy te dwa wątki - uznanie teorii za odbicie rzeczywistości oraz odrzucenie idealizmu - podczas kryzysu intelektualnego, jakiego doświadczył Lenin w 1914 roku, w rezultacie czego zaczął poważnie studiować Hegla. Zmiana, jaka zaszła w tych dwóch punktach Leninowskiego projektu, najpełniej obrazuje oryginalność jego refleksji po 1914 roku. Jak dobrze wiadomo, Lenin w tym okresie zrywał właśnie z marksizmem Drugiej Międzynarodówki. Apelował wówczas o powołanie nowej międzynarodówki, która zmieniłaby wojnę imperialistyczną w wojnę domową, nawet jeśli miałoby to oznaczać zajęcie postawy „rewolucyjnego defetyzmu”. Wraz z Różą Luksemburg, Liebknechtem i Trockim znalazł się pośród nielicznych osób, które stanowczo opowiedziały się przeciwko wojnie, która pochłonęła - jak się miało później okazać - dziesięć milionów ludzkich istnień. Róża Luksemburg za swój zasadniczy sprzeciw wobec wojny trafiła do więzienia.

W Szwajcarii, gdzie znalazł schronienie jesienią 1914 roku, Lenin zaczął po raz pierwszy myśleć o sobie nie tylko jako o przywódcy rosyjskich marksistów, ale jako o architekcie nowej marksistowskiej międzynarodówki mającej powstać na gruzach tej, która rozpadła się wraz z wybuchem wojny. Filozoficzna rekonfiguracja nie dokonywała się więc w warunkach pokoju, z dala od zgiełku bieżącej polityki, lecz w samym środków dziejowej zawieruchy, która wymuszała przemyślenie na nowo dotychczas przyjmowanych założeń. 
Ponadto, Lenin wciąż śledził ruchy liderów Drugiej Międzynarodówki, którzy zdradziwszy socjalizm, pomagali rządom swoich państw wysyłać robotników do okopów na rzeź.

Najbardziej intensywne studia nad Heglem Lenin prowadził w pierwszych miesiącach wojny, między wrześniem 1914 a styczniem 1915 roku. Poważne zmiany w jego światopoglądzie filozoficznym zaczęły zachodzić, gdy zaczął podsumowywać notatki poczynione podczas lektury monumentalnej Nauki logiki. Lenin czytał ją bardzo wnikliwie, wypisując z niej całe ustępy po niemiecku i przeplatając je własnymi komentarzami, zwykle w języku rosyjskim.

Zaczął wówczas odchodzić od schematycznego materializmu, krytycznie przyswajając sobie zarazem Heglowską idealistyczną dialektykę. Podobnie jak wcześniej Engels Lenin również poczuł sympatię dla płynności i elastyczności myśli Hegla: „Pojęcia, które zwykle wydają się martwe Hegel analizuje i pokazuje, że jest w nich ruch" (Lenin 1988, 91). Jednak za chwilę zaczął się zwracać w zupełnie innym kierunku, wykraczającym poza Engelsowską dychotomię „dwóch wielkich obozów [Lager]”6 w filozofii, czyli idealizmu i materializmu:

\begin{abstract}
Myśl o przeobrażaniu się tego, co idealne, w to, co realne, jest głęboka: bardzo ważna dla historii. Ale $\mathrm{i}$ w osobistym życiu człowieka widać, że jest tu dużo prawdy. Przeciwko wulgarnemu materializmowi. NB. Różnica między tym, co idealne, a tym, co materialne, też nie jest bezwarunkowa, nie überschwenglich (Lenin 1988a, 97).
\end{abstract}

Tutaj też po raz pierwszy Lenin wprowadził nową kategorię: „wulgarny materializm”. Dalej w swoich notatkach zauważał, że Plechanow nigdy nie podjął trudu analizy Nauki logiki, która w oczach Lenina była najważniejszym dziełem w dorobku Hegla, w związku z czym odmawiał mu teraz miana „materialisty dialektycznego” i wprost nazywał go „wulgarnym materialistą" (Lenin 1988a, 148). Na nieco bardziej ogólnym poziomie stwierdzić można, że tego typu wypowiedzi lokowały Lenina znacznie bliżej tego, co określa się jako marksizm krytyczny niż pozycji powszechnie uważanych za „ortodoksyjny leninizm”.

$\mathrm{Na}$ dodatek (będzie to później problem dla takich marksistowsko-leninowskich kontynuatorów Spinozy jak Louis Althusser) Lenin zdawał się zgadzać z rozwijaną przez Hegla krytyką deterministycznego systemu Spinozy. Filozofia Spinozy - zauważał Hegel pozbawiona była wolnego i świadomego podmiotu, czyniąc myśl - jak określał to Lenin „atrybutem substancji” (Lenin 1988a, 137). Chcąc uniknąć jednostronności schematycznego materializmu, Lenin w notatkach z Nauki logiki pisał: „jest niedorzecznością negować obiektywność pojęć” (Lenin 1988a, 147). Część jego rozważań poświęcona była właściwym

6 Jak wiadomo, Engels posłużył się tą metaforą o nieco militarnym charakterze - tak jak polski „obóz”, również niemiecki „Lager” może odnosić się do obozu wojskowego - w swojej pracy Ludwik Feuerbach $i$ żmierz̨ch klasycznej filozofii niemieckiej (Engels 1969, 308). 
sposobom krytyki neokantyzmu. Polemizując zarówno ze swymi wcześniejszymi tekstami, takimi jak Materializm a empiriokrytycyzm, jak i z innymi marksistowskimi autorami (np. Plechanowem), stwierdził, że marksiści na początku dwudziestego wieku krytykowali „kantystów i zwolenników Hume’a bardziej po feuerbachowsku (i po büchnerowsku) niż po heglowsku"(Lenin 1988a, 148). Następowała tu rzecz warta odnotowania po raz pierwszy od czasów pism młodego Marksa ważna postać w obrębi tradycji marksistowskiej sugerowała, że podejmuje problem „w duchu heglowskim” bez konieczności natychmiastowego deklarowania swego materializmu. W istocie Lenin postępował w zupełnie przeciwny sposób, odrzucając wulgarny materializm, który w jego ocenie rozwijał materialistyczną, ale nieheglowską, a więc także niedialektyczną krytykę neokantowskiego idealizmu.

To prowadziło bezpośrednio do znanego aforyzmu Lenina, już zresztą tu cytowanego wcześniej: „Nie można w pełni zrozumieć Kapitału Marksa, a zwłaszcza jego I rozdziału, jeżeli się nie przestudiowało i nie rozumiało całej Logiki Hegla. A zatem nikt z marksistów nie zrozumiał Marksa po upływie 1/2 stulecia!!” (Lenin 1988a, 149).

W innym miejscu Lenin pisał o Heglowskiej dialektyce jako o ,wewnętrznym tętnie samorzutnego ruchu i życia" (Lenin 1988a, 117). Stopniowo zaczął dystansować się od swego wcześniejszej refutacji idealizmu. Teraz kluczowe stawało się takie krytyczne przechwycenie dialektycznego idealizmu Hegla, aby powiązać go z Marksowskim materializmem. W przeciwieństwie do Engelsowskiego podziału na dwa wrogie obozy idealistyczny i materialistyczny - Lenin zbliżał się do uznania swego rodzaju dialektycznej jedności idealizmu i materializmu. Nie mógł przy tym wiedzieć, że za czymś podobnym opowiadał się w 1844 roku młody Marks, pisząc, że „konsekwentny naturalizm czy też humanizm różni się zarówno od idealizmu, jak i od materializmu, będąc zarazem prawdą jednocząca je oba" (Marks 1976, 626) ${ }^{7}$.

Ponadto chciałbym bliżej przyjrzeć się rosnącemu sprzeciwowi Lenina wobec wulgarnej teorii odbicia, a więc drugiemu momentowi, w którym dochodziło do zerwania z perspektywa przyjętą w 1908 roku. Najbardziej bezpośrednio ruch ten wyraża stwierdzenie, które pojawia się pod koniec Zesaytón Filozoficznych: „Świadomość człowieka nie tylko odbija świat obiektywny, ale go też tworzy" (Lenin 1988a, 177). Jest to dowód na aktywne, krytyczne i rewolucyjne przejęcie Heglowskiego idealizmu. W tym miejscu poznanie ucieleśnione w rewolucyjnej teorii nie jest jedynie odbiciem materialnych warunków, lecz jest również ich przekroczeniem skierowanym ku tworzeniu nowego świata, wolnego od dehumanizujących

7 Rekopisy ekonomiczno-filozoficzne z 1844 roku, ignorowane przez Drugą Międzynarodówkę (i Engelsa), zostały opublikowane po śmierci Lenina jako część pierwszego Marx-Engels Gesamtausgabe (MEGA). Prace nad pierwszym MEGA (prace nad MEGA² trwają obecnie) rozpoczęto we wczesnych latach dwudziestych zresztą z silnym poparciem ze strony Lenina. Przerwano je za Stalina, który doprowadził do egzekucji ich głównego redaktora, Dawida Riazanowa. 
relacji społecznych tworzonych przez kapitalizm. Ani materializm, ani odbicie materii nie uzyskuja tu więc pierwszeństwa „w najwyższej instancji”. Kierunek wyrażonej myśli jest przeciwny, prowadzi nas od ograniczeń teorii odbicia ku uznaniu, że idee i koncepty moga „,worzyć" świat obiektywny.

Leszek Kołakowski, pomimo bardzo krytycznej oceny Lenina, przyznawał, że jego notatki o Heglu przekraczały Engelsowską ortodoksję, która redukowała dialektykę do przeciwstawienia sobie płynnych i statycznych form. W Gtównych nurtach marksizmu tak pisze on o Zeszytach filozoficznych:

\begin{abstract}
z drugiej strony jednakże główna tendencja tych uwag zmierza ku mniej uproszczonej interpretacji heglizmu aniżeli ta, jaką można było u Engelsa znaleźć; dialektyka nie jest tylko twierdzeniem, że „wszystko się zmienia”, ale pewną próbą interpretacji wiedzy ludzkiej jako nieustannej gry między podmiotem i przedmiotem, takiej gry, w której zaciera się pojęcie „absolutnego prymatu” jednego lub drugiego (Kołakowski 2009, $475-476)^{8}$.
\end{abstract}

\title{
Ruchy narodowowyzwoleńcze, czyli nowa opozycja dialektyczna w erze imperializmu
}

Powszechnie wiadomo, że Imperializm jako najwyìsze stadium kapitalizmu to jedna z najważniejszych prac teoretycznych Lenina. Mało kto jednak zwraca uwagę na relację łącząca ten tekst $\mathrm{z}$ jego pismami poświęconymi ruchom narodowowyzwoleńczym i antyimperialistycznym, a jeszcze rzadziej rozważa się związki pomiędzy Imperializmem a Zeszytami filozoficznymi, które powstały przecież ledwie rok wcześniej. Właśnie temu problemowi chciałbym poświęcić teraz nieco uwagi.

Pośród dzisiejszej lewicy wyraźnie widoczna jest tendencja, aby odrzucać wszelkie formy nacjonalizmu jako reakcyjne. Jest to tym bardziej interesujące, że w poprzednim pokoleniu tendencja zwykle była odwrotna - bezkrytycznie popierano wszelkie formy ruchów wyzwolenia narodowego aktywnych w Trzecim Świecie, od południowej Afryki po Palestynę i od Wietnamu po Kubę. Pisma Lenina, zwłaszcza te powstałe po 1915 roku, dalekie są od bezkrytycznego poparcia dla ruchów narodowych. Jednocześnie jednak Lenin był pierwszym ważnym teoretykiem politycznym - zarówno wśród marksistów, jak i niemarksistów - który dostrzegał doniosłą rolę, jaką w światowej polityce dwudziestego wieku odegrać mogły antyimperialistyczne ruchy narodowowyzwoleńcze.

\footnotetext{
8 Kołakowski to nie jedyny opozycyjny wobec leninizmu filozof, który docenił Zeszyty filozoficzne - innym przykładem może być jeszcze bardziej dogłębne studium Louisa Dupré (1983).
} 
Jak już wspomniano, przed 1914 rokiem Lenin postrzegał samego siebie raczej jako lidera rosyjskiego, a nie międzynarodowego marksizmu. W tym sensie jego trajektoria jest wyraźnie odmienna choćby od tej przyjętej przez Różę Luksemburg, która przed I wojną światową była już ważną postacia na międzynarodowych kongresach socjalistycznych. Dla Lenina natomiast to właśnie czas wojny - jego ówczesna działalność i pisma teoretyczne - oznaczał wkroczenie na scenę prawdziwie ogólnoświatowej polityki rewolucyjnej. Dokonało się to na co najmniej cztery sposoby. Po pierwsze, jak już widzieliśmy, jego notatki o Heglu stanowiły wyraźna próbę rewitalizacji marksistowskiej teorii po zdradzie, jakiej dopuścili się wobec niej socjalistyczni przywódcy w 1914 roku. Po drugie, w swoim Imperializmie ani razu nie wspomina on o Rosji, koncentrując się na wiodących państwach kapitalistycznych - Wielkiej Brytanii, Francji, Niemczech i Stanach Zjednoczonych. To właśnie kryzys 1914 roku sprawił, że Lenin zdecydował się włączyć w debatę, która od około 1910 roku znajdowała się w centrum zainteresowania światowego marksizmu, angażując tak ważnych teoretyków jak Kautsky, Luksemburg czy Hilferding. Także jego pisma dotyczące antyimperialistycznych ruchów wyzwolenia narodowego powstałe po 1915 roku nie koncentrują się jedynie na Rosji, lecz w mniejszym lub większym stopniu dotyczą także Irlandii, Chin, Indii czy Bliskiego i Środkowego Wschodu. Po trzecie, Państwo i rewolucja zaledwie wspomina sytuację w Rosji, będąc raczej teoretycznym traktatem wymierzonym w teorię i praktykę głównego nurtu niemieckiej socjaldemokracji od momentu śmierci Engelsa w 1895 roku. Była to więc wyraźna próba wykreślenia nowych teoretycznych podziałów w skali światowej, nie zaś tylko w kontekście rosyjskiego marksizmu. Po czwarte wreszcie, podejmowane od 1914 roku próby stworzenia nowej międzynarodówki, uwieńczone powodzeniem ostatecznie w 1919 roku, stanowić moga ilustrację tego przesunięcia w bardziej praktycznym wymiarze. Oczywiście pamiętać trzeba, że o imperializmie i państwie pisał również młodszy współpracownik Lenina, Nikołaj Bucharin, publikując zresztą najważniejsze prace na ten temat krótko przed ukazaniem się książek Lenina. Zasadnicze różnice między nimi wyłożone zostały już w niezliczonych tekstach będących próbą zbagatelizowania oryginalności Lenina i sprowadzenia go przede wszystkim do roli politycznego działacza. Widać to choćby w pracach Tony'ego Cliffa i Neila Hardinga, którzy obszernie dowodzą, że zarówno w Imperializmie, jak i Państwie i rewolucji Lenin podąża drogą, która już wcześniej wytyczył Bucharin ${ }^{9}$.

Kiedy jednak Lenin zaczął głosić pogląd, że antyimperialistyczne ruchy wyzwolenia narodowego moga być główną siłą opozycyjną względem kapitalizmu w stadium imperialistycznym, spotkał się ze stanowczą krytyką. Głoszona przez Bucharina teza, że przyspieszona przez wojnę centralizacja światowego kapitału uczyni nacjonalizm

\footnotetext{
9 Alternatywną interpretację proponuje na przykład Raja Dunajewska (1973a; zob. także Anderson 1987).
} 
przestarzałym przeżytkiem, miała znacznie więcej zwolenników w kręgu rewolucyjnej lewicy $^{10}$. Dlatego właśnie Lenin aż do 1917 roku w tzw. kwestii narodowej i kolonialnej znajdował się w mniejszości nawet pośród tych marksistów, którzy zerwali z Druga Międzynarodówką. Widać to wyraźnie w polemicznych komentarzach nie tylko Luksemburg i Bucharina, ale nawet Karola Radka i innych bliskich mu marksistów ${ }^{11}$.

W emigracyjnych tekstach o imperializmie i nacjonalizmie pisanych w latach 19161917 Lenin często odwoływał się do irlandzkiego „powstania wielkanocnego” z 1916 roku, a także do wydarzeń zachodzących w Chinach, Iranie, Turcji i Indiach. Przypadek irlandzki, ze względu na fakt, że był to największy antyimperialistyczny zryw narodowy lat wojny, wywołał szczególnie ostrą polemikę, podczas której Lenin do pewnego stopnia wypracował własną perspektywę. Komentując wybuch powstania, Lenin odwołał się tė do dialektyki: „Dialektyka historii jest tego rodzaju, że małe narody, bezsilne jako czynnik samodzielny w walce $\mathrm{z}$ imperializmem, odgrywają rolę jako jeden $\mathrm{z}$ fermentów, jako jeden $\mathrm{z}$ bakcylów, które ułatwiają wejście na arenę prawdziwej siły antyimperialistycznej, mianowicie: socjalistycznego proletariatu" (Lenin 1987a, 52).

$\mathrm{Na}$ prawym skrzydle rosyjskiej socjaldemokracji Plechanow witał z entuzjazmem upadek „powstania wielkanocnego”, podczas gdy Radek, dawny współpracownik Luksemburg, a obecnie bliski Leninowi, traktował je jako „pucz”: „Ruch zwany Sinn Fein był czysto miejski oraz drobnoburżuazyjny i choć spowodował znaczne zamieszanie, w istocie miał niewielkie poparcie społeczne" (Radek 1984, 375). Trocki w tym sporze lokował się między Leninem a Radkiem, bagatelizując znaczenie rewolty, ale dostrzegając w niej pewien potencjał polityczny, o ile tylko ruch zdołałby przekroczyć swój nacjonalizm. Trocki był kiepskim prorokiem, pisząc, że wraz z rozwojem światowego kapitalizmu „historyczna baza dla rewolucji narodowej zniknęła nawet w zacofanej Irlandii”. Konkludował też, że „eksperyment z irlandzką rebelią” stanowi przykład „zużytych nadziei i metod przeszłości” (Trotsky 1984, 372-373). Do debaty tej nie przywiązywano dotychczas należytej uwagi, po części zapewne dlatego, że cytowane powyżej teksty Radka i Trockiego zostały zbyt późno przetłumaczone na zachodnie języki. Kilka spośród powstałych od lat siedemdziesiątych dłuższych studiów poświęconych Leninowi (zwykle zresztą autorstwa brytyjskich badaczy)

10 Dawała tu o sobie znać spuścizna marksizmu Drugiej Międzynarodówki. Pod koniec lat dziewięćdziesiątych dziewiętnastego wieku Karol Kautsky i Wiktor Adler zdystansowali się wobec silnego poparcia, jakiego kwestii niepodległości Polski oraz Irlandii udzielali Marks i Engels. Także zajmująca pozycje rewolucyjnej lewicy Róża Luksemburg odrzucała wszelkie formy nacjonalizmu jako ideologii burżuazyjnej, choć ona akurat miała na tyle intelektualnej szczerości, by wprost mówić, że w tej kwestii nie zgadza się ze stanowiskiem Marksa i Engelsa.

11 Pomijam tutaj omówienie trzeciego stanowiska w tej debacie, czyli koncepcję autonomii narodowej i kulturalnej Otto Bauera. 
w ogóle nie wspomina o stosunku Lenina do Irlandii albo też poświęca tej sprawie niewiele miejsca $^{12}$.

Lenin zaś nieustannie pisał o setkach milionów ludzi uciskanych przez globalny imperializm i ich pragnieniu wyzwolenia. Dostrzegał wyraźną różnicę między wyzwoleńczym ruchem w obrębie uciskanego narodu a szowinizmem narodu uciskającego. Wyzwolenie narodowe stanowiło dla niego dialektyczne przeciwieństwo globalnego imperializmu, podczas gdy nacjonalizm wielkich europejskich mocarstw - Stanów Zjednoczonych i Japonii promował i podtrzymywał imperializm. Ci, którzy minimalizują teoretyczny wkład Lenina w tej dziedzinie albo też postrzegaja go jako wyłącznie taktyczny, powinni dostrzec jego zdolność przewidywania w tej materii. Ponad trzy dekady przed uzyskaniem przez Indie niepodległości i prawie pięć dekad przed tym, jak na pierwszy plan wysunęły się afrykańskie ruchy wyzwoleńcze, Lenin już analizował na gruncie teoretycznym antyimperialistyczne ruchy wyzwolenia narodowego jako główny czynnik w światowej polityce.

Krytykując w 1916 roku swoich młodych bolszewickich towarzyszy za formalistyczne odrzucenie wszelkich form nacjonalizmu, nasuwające na myśl postawę Bucharina, Lenin oskarżał ich o to, że chca „malować sobie [...] przyszłość jednobarwną szarawą farbą” (Lenin 1987b, 116): „Rewolucja socjalna nie może dokonać się inaczej niż w postaci epoki, w której wojnie domowej proletariatu z burżuazja w krajach przodujących towarzyszyć będzie sžereg demokratycznych i rewolucyjnych - między innymi narodowowyzwoleńczych - ruchów wśród narodów nierozwiniętych, zacofanych i uciskanych" (Lenin 1987b, 106).

Także w jednym ze swoich ostatnich tekstów, O naszej rewolucji (W zwiazku znotatkami N. Suchanowa), Lenin atakowal tych, którzy chcieliby zamknać partykularne, nieeuropejskie ścieżki rozwoju w jednym abstrakcyjnym schemacie:

Wszyscy oni nazywają siebie marksistami, pojmuja jednak marksizm do niemożliwości
pedantycznie. Nie zrozumieli zupełnie tego, co w marksizmie jest decydujące,
mianowicie: jego rewolucyjnej dialektyki. Absolutnie nie zrozumieli nawet wyraźnych
wskazań Marksa, że w czasie rewolucji konieczna jest maksymalna elastyczność $[\ldots]$
znali dotychczas określoną droge rozwoju kapitalizmu i demokracji burżuazyjnej
w Europie Zachodniej. I oto nie mogą sobie wyobrazić, że ta droga może być
uważana za wzór mutatis mutandis, to jest nie inaczej niż z pewnymi poprawkami [...]
$\mathrm{Na}$ przykład nie przychodzi im nawet do głowy, że Rosja, znajdująca się
na pograniczu krajów cywilizowanych i krajów po raz pierwszy przez tę wojnę
ostatecznie wciagniętych w krag cywilizacji, krajów całego Wschodu, krajów

12 Następujące prace zupełnie nie wspominają o artykułach Lenina na temat irlandzkiego powstania: Service 2000, Cliff 1974-1979, Harding 1981, Harding 1996; wcześniejsza książka Service’a (1985; 1991; 1996) poświęca tylko kilka linijek wydarzeniom irlandzkim z 1916 roku. Podobnie niewiele wnosi praca Liebmana (1975), która w ogóle tylko w pobieżny sposób traktuje o imperializmie i ruchach narodowowyzwoleńczych. 
pozaeuropejskich, że Rosja mogła i musiała wskutek tego przejawić pewne cechy swoiste" (Lenin 1989b, 370-371).

Jak podkreślił to Lenin w przytoczonym cytacie, ich postawa była wynikiem odrzucenia dialektycznej perspektywy.

W tym sensie jego studia nad Heglem i pisma na temat wyzwolenia narodowego stanowiły całość. Rok wcześniej, w 1922 Lenin wezwał do podjęcia w Rosji Radzieckiej studiów nad Heglowską dialektyką, wiążąc je z rozwijającym się ruchem uciskanych i skolonizowane narodów:

\begin{abstract}
Aby osiagnąc ten cel, współpracownicy czasopisma „Pod Znamieniem Marksizmu” powinni organizować systematyczne studiowania $-\mathrm{z}$ materialistycznego punktu widzenia - dialektyki Hegla, tzn. tej dialektyki, którą Marks stosował w praktyce zarówno w swym Kapitale, jak i w swych pracach historycznych i politycznych, i stosował z takim powodzeniem, że obecnie każdy dzień, kiedy do życia i do walki budzą się nowe klasy na Wschodzie (Japonia, Indie, Chiny) - tj. te setki milionów ludzi, którzy stanowią większość ludności kuli ziemskiej, a których bierność historyczna i historyczny letarg powodowały dotychczas zastój i gnicie w wielu przodujących państwach Europy - każdy dzień, kiedy do życia budzą się nowe ludy i nowe klasy, potwierdza coraz bardziej słuszność marksizmu (Lenin 1989a, 29).
\end{abstract}

Jak można zauważyć, tylko pierwsza część tej wypowiedzi (z pominięciem antyimperialistycznych ruchów w Azji) znalazła się w epigramie otwierającym Marksiźm i Filozofie Karla Korscha. W ten sposób Korsch odgrodził murem dyskusję o Heglu i dialektyce, czyniąc ją „zachodnią” sprawa. Odrzucił to, z czym wyraźnie się nie zgadzał, a więc objęcie przez Lenina w tym cytacie nowych „wschodnich” ruchów wyzwoleńczych. Ten rodzaj rozdzielenia miał zubożyć wiele późniejszych zachodnich dyskusji o dialektyce.

\title{
Międzynarodowy wpływ pism Lenina o wyzwoleniu narodowym: nowe głosy z Indii, Iranu i Czarnej Ameryki
}

Wprowadzonego przez Lenina nowego ducha do marksizmu z łatwością dostrzec można było podczas debat prowadzonych w 1920 roku na II Kongresie Międzynarodówki Komunistycznej. Leninowski Pierwotny sqkic tez w kwestii narodowej i kolonialnej odnosił się nie tylko do wyraźnie geograficznie wyodrębnionych narodów, jak Irlandczyków czy Ukraińców, ale również do mniejszości narodowych, takich jak „Murzyni w Ameryce” (Lenin 1988b, 155). Grigorij Zinowjew był jednym z nielicznych bolszewików, którzy już podczas I wojny światowej podzielali znaczną część poglądów Lenina w kwestii problemu walki o wyzwolenie narodowe. Jednak gdy niemal nazajutrz po rozpoczęciu obrad Kongresu Międzynarodówki 
przemawiał on w Baku na Kongresie Ludów Wschodu przed publicznością, która składała się w większości z przedstawicieli społeczeństw muzułmańskich, pozwolił sobie na wezwanie do „świętej wojny w pierwszym rzędzie przeciwko brytyjskiemu imperializmowi” (zob. Riddell 1993, 78). Lenin natomiast w tezach z tego samego roku wzywał do „walki z panislamizmem” (Lenin 1988b, 155), jednak podkreślał, że „konieczna jest bezpośrednia pomoc wszystkich partii komunistycznych dla ruchów rewolucyjnych wśród narodów zależnych lub nierównouprawnionych (np. Irlandii, wśród Murzynów Ameryki itp.) oraz w koloniach" (Lenin 1988b, 159).

Podczas II Kongresu Międzynarodówki Komunistycznej odbyto wyjątkowo poważna i wyczerpująca debatę na temat imperializmu i problemu ruchów wyzwolenia narodowego. Jako uzupełnienie tez Lenina zaprezentowane zostało stanowisko M.N. Roy'a, znanego indyjskiego marksisty, który zgadzał się z Leninem co do tego, że „obalenie imperium kolonialnego $\mathrm{w}$ połączeniu $\mathrm{z}$ rewolucją proletariacką $\mathrm{w}$ metropolii doprowadzi do obalenia kapitalizmu w Europie" (Riddell 1991, 219). Inne fragmenty jego wystapienia pod pewnymi względami były jednak polemiczne względem rosyjskiego rewolucjonisty. Roy atakował na przykład „koteryjność burżuazyjno-demokratycznego nacjonalizmu”, jednocześnie z większym niż Lenin wahaniem przyznając, że „rewolucyjny nacjonalizm odegra w przyszłości istotną rolę" (Riddell 1991, 223-224).

Ceniony irański marksista Avetis Sułtanzade ${ }^{13}$, którego stanowisko było nieco bliższe pozycjom Lenina, opowiadał się za wzajemnym przenikaniem się ruchów antyimperialistycznych i ruchu robotniczego na obszarach rozwiniętego kapitalizmu:

\begin{abstract}
Druga Międzynarodówka rozważała problem kolonializmu na większości swoich kongresów, opracowując bardzo eleganckie rezolucje, które jednak nigdy nie były wcielane w życie. Często zresztą dyskutowano i uchwalano rezolucje w tych sprawach bez udziału przedstawicieli państw zacofanych. Co więcej, gdy rosyjscy i brytyjscy kaci dławili pierwszą perską rewolucję $e^{14}$, a perscy socjaldemokraci prosili o pomoc europejski proletariat, reprezentowany wtedy właśnie przez Drugą Międzynarodówkę, nie pozwolono im nawet poddać własnej rezolucji pod głosowanie (Riddell 1991, 238).
\end{abstract}

Sułtanzade dodawał równiė̇, z rzadkim na tego typu kongresach poczuciem politycznego realizmu, że „to prawda, że rozwój kapitalizmu w koloniach budzi rewolucyjne nastroje, ale prawdą jest też, że kapitalistyczny wyzysk kolonii rodzi kontrrewolucyjne nastroje wśród arystokracji robotniczej kolonialnych metropolii” (Riddell 1991, 238). Rewolucja 1917

\footnotetext{
13 Sułtanzade zginął w stalinowskich czystkach i dlatego ostentacyjnie proradziecka partia Tudeh w ogóle wymazała jego nazwisko ze swojej oficjalnej historii.

14 Więcej o tym często zapominanym i w zadziwiającym stopniu świeckim powstaniu, zob. Afary 1996.
} 
roku - konkludował - wytworzyła jednak nową sytuację: „Piorun rewolucji na Zachodzie wstrząsnął Orientem aż do fundamentów, dodając sił rewolucjonistom w Persji i Turcji”" (Riddell 1991, 239).

Amerykański dziennikarz John Reed omawiał podczas kongresu akty rasistowskiej przemocy i samoobronę czarnych społeczności podczas zamieszek 1919 roku:

Do pierwszego wybuchu doszło w stołecznym Waszyngtonie, gdzie dawni niżsi urzędnicy administracji rządowej, wracając jako weterani $z$ wojny, na swoich dotychczasowych posadach zastali nowych, czarnych urzędników. Okazało się przy okazji, że większość tych urzędników-weteranów pochodzi z Południa. Zaczęli teraz organizować nocne napaści na dzielnice zamieszkane przez czarnych, aby ich sterroryzować i zmusić do oddania im ich dawnych posad. Ku zdziwieniu niemal wszystkich na ulice wylegli w pełni uzbrojeni czarni mieszkańcy i rozgorzała bitwa [...]” (Riddell 1991, 226-227).

Po opisaniu podobnych wydarzeń w pozostałych miastach, między innymi w Chicago, Reed stwierdzał: „Podczas wszystkich tych starć czarni pokazali po raz pierwszy w historii, że sa uzbrojeni, dobrze zorganizowani i nie czują jakiegokolwiek strachu przed swymi białymi przeciwnikami. Ich opór poskutkował, po pierwsze, spóźnioną interwencją rządu, po drugie, zaś otwarciem się Amerykańskiej Federacji Pracy na czarnych robotników” (Riddell 1991, 227).

Od czasów samego Marksa żadne wydarzenie nie wstrząsnęło tak mocno stanowiskiem amerykańskich marksistów w kwestii rasowej.

Podczas IV Kongresu Międzynarodówki Komunistycznej w 1924 roku, na którym znany czarny pisarz Claude McKay piastował mandat członka amerykańskiej delegacji, po raz pierwszy odbyła się sesja w całości poświęcona „problemom czarnych”. Podczas gdy Reed cztery lata wcześniej po prostu krytykował postawę białych robotników, McKay kierował swój atak na stanowisko w kwestii problemów rasowych zajmowane przez samych socjalistów i komunistów w Stanach Zjednoczonych:

Podczas gdy nawet reformatorsko zorientowana burżuazja amerykańska zwalczała dyskryminację i uprzedzenia rasowe, nasi socjaliści i komuniści tylko bardzo nieśmiało występowali w tej kwestii. Dzieje się tak, ponieważ poważna część z tych uprzedzeń jest podzielana również $\mathrm{w}$ ich szeregach, wobec czego też niechętnie mierzą się oni z kwestia problemów czarnej ludności. Działając wspólnie z innymi amerykańskimi towarzyszami, zetknąem się z manifestacjami tych uprzedzeń przy wielu okazjach, gdy czarni i biali towarzysze mieli występować wspólnie. Jest to największa przeszkoda, która przezwyciężyć muszą komuniści w Ameryce - najpierw muszą 
wyzwolić sami siebie z uprzedzeń względem czarnych, a dopiero później będą mogli dotrzeć do nich ze swoimi radykalnymi hasłami.

McKay mówił również o tym, jak poruszająco na opinię Afroamerykańską wpłynęła prezentacja stanowiska Marksa w kwestii niewolnictwa i rasizmu:

\begin{abstract}
W 1918 roku, gdy Trzecia Międzynarodówka ogłosiła swój manifest zawierający tezy odnoszące się do wyzyskiwanych kolonii, niektóre grupy czarnych radykalnych aktywistów w Ameryce przystapiły do propagowania tych idei wśród ludu. Gdy w 1920 roku amerykański rząd zaczął śledzić i prześladować odpowiedzialnych za prowadzenie radykalnej propagandy wśród czarnych, mała grupa radykałów zrewanżowała się w ten sposób, że nagłośniła fakt, że to właśnie socjaliści opowiadaja się za wyzwoleniem czarnych, a reformatorsko zorientowana Ameryka nic w tej kwestii nie robi. Sądzę, że właśnie wtedy po raz pierwszy w historii tego kraju amerykańscy czarni uświadomili sobie, że Karol Marks opowiadał się za ich emancypacja i bezkompromisowo o nia walczył (Fourth Congress of the Communist International 1924, 260-261).
\end{abstract}

Występując na rzecz jedności robotników ponad podziałami rasowymi, McKay wzywał również zdominowane przez białych organizacje pracownicze i socjalistyczne, aby mocniej wsparły ruch czarnych. Owocem tej bezprecedensowej sesji był także przygotowany przez niego maszynopis ksiazżi The Negroes in America (McKay 1979) ${ }^{15}$, zamówionej przez Komintern, a także publiczna dyskusja McKay'a i Trockiego przeprowadzona na łamach rosyjskiej prasy.

Choć Trocki nigdy nie odegrał poważniejszej roli w dyskusjach o dialektyce, to w latach trzydziestych w kwestii ruchów narodowowyzwoleńczych zbliżył się do stanowiska, które zajmował Lenin. Jednym z tego przykładów jest przeprowadzona w 1939 roku dyskusja z karaibskim myślicielem marksistowskim, C.L.R. Jamesem, wówczas już zresztą zadeklarowanym trockista. Podczas dyskusji na temat utworzenia niestalinowskiej organizacji, która zrzeszałaby czarnych radykałów, Trocki stwierdził: „nie wiem, jak czarna burżuazja może pomóc czarnemu proletariatowi w jego walce o poprawę pozycji ekonomicznej”. James odpowiadał na to następująco: „niektórzy w naszym ruchu należą do drobnej burżuazji. Jeśli czarny burżua nie może studiować na uniwersytecie z powodu koloru swojej skóry, nasza organizacja najpewniej zmobilizuje masy do walki o prawa

15 Amerykańska partia komunistyczna wyraźnie nie była zainteresowana tą książką, w związku z czym zdawało się, że jej angielski tekst zaginął. Na potrzeby cytowanego tu wydania z 1979 roku książka została ponownie przetłumaczona z wersji rosyjskiej, także nieopublikowanej, lecz przechowywanej w maszynopisie w New York Public Library. Więcej o interwencji McKay’a na kongresie w 1924 roku, zob. Dunayewskaya 1963. 
czarnego, burżuazyjnego studenta”. Trocki: „Jestem przekonany, że podstawową kwestia jest stanowisko (trockistowskiej) Socjalistycznej Partii Robotniczej [Socialist Workers Party] wobec czarnych. To bardzo niepokojące, że do tej pory partia nie zrobiła niemal nic w tej kwestii. Nie opublikowano książki, broszury, ulotki, ani nawet artykułu w New International. [...] Jak widać i naszej partii grozić może degeneracja”. Trocki zdawał się być bardzo otwarty na nowe formy antyrasistowskiej organizacji. Zauważał też, że jeśli chodzi o segregację rasowa, partia trockistowska może pod pewnymi warunkami wesprzeć czarnych członów Partii Demokratycznej w ich walce z białymi współtowarzyszami: „Uważamy, że rozróżnienie czarnych i białych kandydatów, nawet jeśli jedni i drudzy wywodzą się z tej samej partii, jest ważnym czynnikiem w walce czarnych o równość i w takich sytuacjach możemy udzielić im warunkowego poparcia" (Trotsky 1967, 42, 48).

Innym świadectwem zmian, jakie zachodziły w sposobie, w jaki Trocki myślał o kwestiach narodowego wyzwolenia, była ewolucja jego stanowiska wobec nacjonalizmu żydowskiego po objęciu władzy przez Hitlera i po odwołaniu się do antysemickich uprzedzeń przez Stalina podczas czystki w latach trzydziestych. W wywiadzie dla pewnego żydowskiego dziennika w 1937 roku tak opisywał zmiany, jakie zaszły w jego stanowisku:

W czasach młodości skłaniałem się raczej ku prognozom przewidującym, że Żydzi w poszczególnych krajach ulegną procesowi asymilacji i tym samym kwestia żydowska zniknie w sposób niejako automatyczny. Jednak rozwój historyczny w ostatnim dwudziestopięcioleciu nie potwierdził tych przewidywań. Rozkład kapitalizmu wszędzie doprowadził do spotęgowania nacjonalizmu, którego komponentem jest również antysemityzm. Kwestia żydowska szczególnie zaciążła nad krajem najbardziej rozwiniętego kapitalizmu w Europie, czyli nad Niemcami. Z drugiej strony Żydzi w różnych krajach stworzyli własną prasę i rozwinęli język jidysz tak, że stał się on instrumentem nowoczesnej kultury. Trzeba wobec tego liczyć się z faktem, że naród żydowski w nadchodzącej epoce wciąż będzie istniał (Trotsky 1970, 20; zob. także Traverso 1994).

Dzisiaj kwestia rasowa, etniczna i imperializm przyjmuja inne formy, ale pomimo rychłego końca bezpośrednich rządów kolonialnych, wzorce wyzysku i ucisku narodów Afryki, Azji, Środkowego Wschodu i Ameryki Łacińskiej przez zamożne kraje kapitalistyczne wciąż istnieja. Pod wpływem tego wyzysku narodziły się ruchy wyzwoleńcze uciskanych przez imperializm narodów, a także ruchy działające w państwach imperialistycznych na rzecz solidarności z uciskanymi narodami kolonialnymi. Jednym z przykładów ich współdziałania była walka $z$ apartheidem w Afryce Południowej. Pokolenie wcześniej, od Chin po Jugosławię i od Francji po Polskę rozwijały się narodowe ruchy oporu walczące $z$ faszyzmem. Wiele z nich zainspirowało studia teoretyczne, kontynuujące analizy podjęte w pismach Lenina. Przykład niech stanowią prace C.L.R. Jamesa i Rai Dunajewskiej, na różne 
sposoby próbujące wykorzystać Leninowskie koncepcje do analizy afrykańskich ruchów narodowowyzwoleńczych lat pięćdziesiątych i sześćdziesiątych, choć przecież sam Lenin w zasadzie nie odnosił się bezpośrednio do problemów Afryki (zob. James 1977; Dunayevskaya 1984).

Tym, co odróżnia naszą dzisiejszą sytuację, obok oczywiście trwającego wciąż panowania zglobalizowanego kapitalizmu, jest fakt, że dawniej skolonizowane lub okupowane narody, zdobywszy sobie niepodległość, moga teraz same stać się opresorami wobec mniejszości narodowych w ich granicach lub nawet poza nimi. Z tej perspektywy skłonność Lenina do rozróżniania różnych form nacjonalizmu, które mogły sprzyjać reakcyjnej albo emancypacyjnej polityce, staje się szczególnie aktualne. Jego uwagi o reakcyjnym nacjonalizmie nie były ograniczone do wielkich mocarstw takich jak Wielka Brytania czy Stany Zjednoczone, jak już bowiem zauważono, Lenin potępiał też na przykład ruch panislamistyczny nawet pomimo tego, że występował on ostro przeciwko brytyjskiemu imperializmowi na Bliskim Wschodzie. Co więcej, przez całe życie krytykował ruch panslawistyczny, wskazując na związki, jakie łączyły go z rosyjskim imperializmem i polityka ucisku mniejszości narodowych w granicach carskiego imperium. Odwołując się do jego pism i czyniąc je punktem wyjścia dla swoich analiz, wielu autorów przez ostatnią dekadę kształtowało swoją ostrą krytykę aktów ludobójstwa serbskiego nacjonalizmu na Bałkanach, jednocześnie jednak wspierając - często z pewną rezerwa - bardziej emancypacyjny ruch narodowy Kosowian, a zwłaszcza Bośniaków wywodzących się z dawnej Jugosławii (zob Hudis i in. 1996; 2000; Landy 1999). Inny przykład politycznej złożoności kwestii narodowej stanowić może ruch zapatystowski w Meksyku, który początkowo reprezentował rdzenne społeczności, których interesy pominięto podczas rewolucji w 1910 roku, a który obecnie zdobył sobie masowe poparcie w całym Meksyku, a także znaczące wsparcie ze strony międzynarodowego ruchu alterglobalistycznego.

\section{Wpływ Lenina na późniejsze debaty na temat dialektyki: od Henriego Lefebvre'a do Rai Dunajewskiej}

Zajmując stanowisko polemiczne względem szkoły frankfurckiej, dwa nurty dwudziestowiecznego marksizmu sięgnęły po pisma Lenina o Heglu, czyniąc je absolutnie kluczowymi dla swego rozumienia dialektyki w ogóle. We Francji był to Henri Lefebvre, a w Stanach Zjednoczonych C.L.R. James, a w szczególności Raja Dunajewska. W jednym i drugim wypadku doprowadziło to do rozwinięcia nowych form heglowskiego marksizmu, po części właśnie za sprawą dyskusji o relacji łączącej Lenina i Hegla.

Tylko niewiele osób poza Francja zdaje sobie sprawę z tego, że Lefebvre (wspólnie z Norbertem Gutermanem) już w 1938 roku opublikował niezależne, akademickie 
tłumaczenie leninowskich zeszytów o Heglu (pięć lat wcześniej ta dwójka wydała też „Krytykę heglowskiej dialektyki i filozofii w ogóle” Marksa z 1844 roku). Wydane przez Éditions Gallimard, a więc do dziś najbardziej prestiżowe wydawnictwo we Francji, Cahiers sur la dialectique d'Hegel sprawiły, że pisma Lenina o Heglu zostały dostrzeżone w kręgu francuskiej opinii intelektualnej. Proces recepcji nastapił więc tu w specyficzny sposób, w przeciwieństwie do Niemiec czy obiegu anglojęzycznego, gdzie dyskusja o tekstach Lenina na temat Hegla zwykle ograniczała się do wąskiego kręgu zwolenników lub, częściej, przeciwników Lenina wśród akademickich specjalistów. Liczące 130 stron wprowadzenie Lefebvre’a i Gutermana do francuskiego przekładu ledwie wspominało o książce Materializ̧m a empiriokrytycyźm przy okazji omówienia procesu rozwoju myśli Lenina między latami 1908 a 1914. Atakując tych wszystkich, którzy chcieli korzystać z Heglowskiej metody i odrzucając jednocześnie Heglowski system, ich wprowadzenie otwierało nowe pole do dyskusji (zob. także Burkhard 1999). Zamiast tego wskazywali oni, że sięgać i wykorzystywać należy samą „treść filozofii Hegla”. Był to też ukłon wobec ortodoksji partii komunistycznej, choć z drugiej strony autorzy nie wspomnieli, że było to również stanowisko zajmowane przez Engelsa.

Kolejne pisma Lefebvre’a o Leninie i Heglu były jeszcze bardziej oględne. Dotyczy to zarówno Logique formelle, logique dialectique oraz jego największego studium, La Pensée de Lenine. Dopiero jednak po tym, jak wyrzucono go z Francuskiej Partii Komunistycznej, Lefebvre ostatecznie otwarcie stwierdził, o jaką stawkę przez cały czas toczył grę. W 1959 roku w swojej autobiografii (La Somme et la reste) Lefebvre pisał o Leninie następująco: „Przed 1914-1915 nie czytał, ani nie studiował poważnie Hegla. Co więcej, jeśli rozważyć to obiektywnie, istnieją wielkie różnice w tonie i treści zeszytów o Heglu oraz książki Materializm a empiriokrytycyzm. Myśl Lenina stała się giętka, pełna życia [...] słowem, dialektyczna. Przed 1914 rokiem, gdy upadła Międzynarodówka, Lenin tak naprawdę nie rozumiał dialektyki”. W przypisie Lefebvre dodaje jeszcze: „Tutaj widać znaczenie, jakie miała wstrzemięźliwość stalinistów w kwestii Zeszytón filozoficznych, które przez długi czas spychano na drugi plan na rzecz pracy Materializm a empiriokrytycyzm” (Lefebvre 1959, 85).

Tak późne stwierdzenie na temat istoty problemu, dokonane na dodatek nie w którejś z najważniejszych książek Lefebvre’a czy w jednym z jego studiów o Leninie, ale w formie luźnego stwierdzenia w bardzo długiej autobiografii, otwierało w latach sześćdziesiątych i siedemdziesiątych drzwi przed różnymi antydialektycznymi, antyheglowskimi i protomaoistowskimi (zob. Elliott 1987) interpretacjami Louisa Althussera i jego szkoły. Widać to szczególnie wyraźnie w jego eseju Lenin i filozofia. Tekst ten przedstawiony został w 1968 roku jako publiczny wykład, przy czym koncentrował się on na książce Materializm a empiriokrytycyzm oraz pismach ekonomicznych Lenina bez wspominania o jego notatkach poświęconych Heglowi. Gdy Jean Hyppolite publicznie 
zwrócił na to uwage, Althusser ostatecznie napisał odrębny artykuł o Zeszytach filozoficznych. Zarówno w nim, jak i w innych swoich komentarzach o Leninie i Heglu, Althusser był często pokrętny, przypisując Leninowi krytykę Hegla w oparciu o zestawienia różnych tekstów, które w istocie sobie przeczyły. Na przykład w odpowiedzi na znane stwierdzenie, cytowane już zresztą tu wcześniej, że należy studiować Nauke logiki Hegla, aby pojąć w pełni Kapitat Marksa, Althusser poddawał słowa Lenina faktycznej „dekonstrukcji”, na koniec przekonując czytelnika w raczej stanowczy sposób, że ,jest niemożliwym zrozumienie Hegla bez dogłębnego przestudiowania i zrozumienia Kapitału” (Althusser 1971, 112). Próbując wyrugować Hegla z myśli Lenina, Althusser realizował kluczowa część swego całościowego projektu wyrugowywania Hegla z marksizmu w ogóle. W istocie więc każda wzmianka o powrotnym zainteresowaniu Lenina dziełem Hegla stanowiła poważne zagrożenie dla całej szkoły Alhtusserowskiej, która twierdziła przecież, że Marks wyzbył się swego heglizmu już w 1846 roku. Jeśli więc w 1914 roku Lenin naprawdę wrócił do Hegla, wówczas znacznie trudniej marksistom byłoby sprawić, „by fantom ów na powrót pogrążył się w ciemności” (Althusser 2009, 143), jak proponował to Althusser w 1962 roku.

W Stanach Zjednoczonych C.L.R. James oraz Raja Dunajewska zaczęli pisać o Leninie i Heglu w latach czterdziestych. W 1948 roku James spisał nieco roboczych uwag na ten temat, później zresztą opublikowanych drukiem (James 1980). W 1949 roku Dunajewska przełożyła natomiast w całości zapiski Lenina o Heglu, miała jednak problem ze znalezieniem wydawcy. Było to najpewniej spowodowane opozycją wobec Hegla, zakorzenioną w pozytywistycznej tradycji i powszechną wówczas w Stanach Zjednoczonych, nawet wśród cenionych lewicowych filozofów takich jak Sidney Hook. W przeciwieństwie do Lefebvre’a James i Dunajewska należeli do ruchu trockistowskiego, choć uznając zeszyty o Heglu za ważną część swego filozoficznego stanowiska, w wielu kwestiach zbliżali się do pozycji dość odległych od trockistowskiej ortodoksji. Po pierwsze, rozwijali bowiem teorię kapitalizmu państwowego jako narzędzia opisu stalinowskiej Rosji. Po drugie, krytykowali leninowską koncepcje partii-awangardy jako elitarna i antydialektyczną. Po trzecie, nawoływali do systematycznych studiów na temat dialektyki opartych na dziełach Hegla, Marksa i Lenina, szkicując jednocześnie wyraźną linię oddzielająca filozoficzne stanowisko Lenina z 1908 i z okresu po 1914 roku. Po czwarte wreszcie, stawiali tezę, że Afroamerykanie są niezależną i potencjalnie rewolucyjną silą opozycyjną wobec amerykańskiego kapitalizmu.

W latach pięćdziesiątych i sześćdziesiątych, po tym jak ich drogi się rozeszły, Dunajewska rozwinęła te wstępnie tylko zarysowane intuicje jako część większego projektu nazwanego przez nią marksizmem humanistycznym. Żaden marksistowski myśliciel przed nią i po niej nie wgryzł się tak głęboko w leninowskie zeszyty o Heglu ani nie podszedł do nich z taką inwencja. Dunajewska uczyniła z tych zapisków fundament projektu zupełnie współczesnej dialektyki rewolucji. Jej zasługą było między innymi pionierskie, przedstawione 
w niniejszym artykule, połączenie leninowskiej perspektywy w kwestii dialektyki z ruchami narodowowyzwoleńczymi. Opublikowała również pierwsze angielskie tłumaczenie większej części Marksowskich Rekopisów z 1844 roku, które wspólnie z zapiskami Lenina o Heglu stanowiły dodatek do jej książki Marxism and Freedom. W innej pracy - Philosophy and Revolution - Dunajewska potraktowała wspólnie powrót Lenina do Hegla oraz poświęcone Heglowi pisma Marksa, czyniąc je częścią dyskusji na temat „Dlaczego Hegel? Dlaczego teraz?”. Jak pisała:

Leninowi z pewnością nie chodziło o to, że każdy, kto chce studiować Kapitał musi koniecznie wcześniej przeprawić się przez dwa tomy Nanki logiki. Tym, co było dla Lenina w tym wypadku kluczowe, było zerwanie z dawnymi konceptami, które w sposób najbardziej jednoznaczny wyraził w formule głoszacej, że „świadomość nie tylko odbija świat, lecz także go współtworzy” [...] Lenin odnalazł u Hegla zupełnie nowy sposób rozumienia jedności materializmu i idealizmu, który później wypełnił jego pisma z okresu po 1915 roku (Dunayevskaya 1973b, 103).

Jednocześnie jednak Dunajewska sformułowała kilka krytycznych uwag o użytkach, jakie Lenin czynił z dzieła Hegla. Po pierwsze, zwracała uwagę, że w zasadzie jego spuścizna w tej kwestii jest niejednoznaczna, a on sam nigdy nie odniósł się w sposób bardziej otwarty do zmiany, jaka nastapiła w jego myśleniu o Heglu i dialektyce:

\begin{abstract}
Nacisk, jaki Lenin kładł na „właściwą dialektykę, jako naukę filozoficzną” odróżniał go od wszystkich pozostałych postmarksowskich marksistów, nie tylko do czasu rewolucji rosyjskiej, ale również po zdobyciu władzy. [...] Tym, co najmocniej eksponowane jeśli chodzi o efekty jego studiów nad Heglem z lat 1914-1915 jest przekonanie o tym, że dialektyka Heglowska musi być studiowana „w sobie i dla samej siebie”. [...] To właśnie Lenin uzyskał dzięki bezpośredniemu kontaktowi z dialektyka Heglowską - jak widać to w jego streszczeniu Nanki Logiki - jednocześnie odsłaniając grzęzawisko ekonomizmu, w którym pograżzona była nie tylko niemiecka socjaldemokracja, lecz cała Druga Międzynarodówka, podczas gdy rewolucjonista powinien stać na twardym gruncie! (Dunayevskaya 1991, 116).
\end{abstract}

Dla Dunajewskiej wszystko to sprzężone było jednak z faktem, że Lenin zgodził się na wznowienie w 1920 roku swojej pracy Materializm a empiriokrytycyzm. Dla porządku dodać trzeba, że nie oddał tej pracy do przekładu na inne języki, tak jak uczynił to choćby z Imperializmem czy Panstwem $i$ rewolucja. Jednak w 1927 roku ulegający stalinizacji aparat doprowadził do wydania jej w tłumaczeniu na wiele zagranicznych języków, a partie komunistyczne na świecie uczyniły $\mathrm{z}$ niej oręż $\mathrm{w}$ brutalnych atakach na idealizm i rozliczeniach intelektualistów, między innymi właśnie Lefebvre’a. 
Drugi nurt krytyki leninowskiej dialektyki opierał się u Dunajewskiej na uznaniu, że Lenin nadmiernie wyeksponował praktyczną, aktywistyczną stronę dialektyki, minimalizując jednocześnie jej rangę teoretyczną. Szczególnie wyraźnie miało być to widoczne w jego rozważaniach nad fragmentem poświęconym idei dobra, który znajduje się w końcowej części Nauki logiki.

Po trzecie, Dunajewska zauważała, że Lenin w kilku miejscach interpretował Hegla w duchu zbyt ciasnego materializmu. Szczególnie widać to w jego dociekaniach na temat ostatnich stron Nauki logiki poświęconych idei Absolutu. Prawdą jest, że Lenin częściowo odrzucił uwagi Engelsa z rozprawy Ludwig Feuerbach $i$ zmierzch klasycznej filozofii niemieckiej głoszące, że Heglowska idea Absolutu uosabia niedialektyczne i abstrakcyjnie idealistyczne wyobrażenie o końcu historii. Dla Engelsa idea Absolutu była szczególnie wyraźną manifestacją Heglowskiego „systemu”, który należało, jego zdaniem, odrzucić na rzecz Heglowskiej dialektycznej „metody”. W Ludwigu Feuerbachu, pisanym na długo po okresie młodzieńczego entuzjazmu do Hegla, Engels nie przytoczył jednak żadnego cytatu, który mógłby potwierdzić ten wniosek. Prawdopodobnie stało się tak, ponieważ nieszczególnie był w stanie jakikolwiek znaleźć. Lenin natomiast w toku swoich uważnych studiów nad ostatnim rozdziałem Nauki logiki podążył inną ścieżką, argumentując, że fragment o idei Absolutu nie zawiera w sobie wcale więcej idealizmu niż materializmu, a wobec tego może być użyteczny dla marksizmu. Dunajewska mimo to twierdziła jednak, że choć Lenin rozważył ten problem głębiej, niż wcześniej uczynił to Engels, to obydwaj nie ustrzegli się istotnych błędów. Lenin przykładał niewiele wagi do centralnej dla Hegla koncepcji negatywności, koncentrując się zamiast tego na problemie sprzeczności. Była to cena, jaka przyszło mu zapłacić za nieznajomość Marksowskich rozważań o dialektyce negatywnej z Rękopisów z. 1844 roku, które w 1914 roku wciąż spoczywały w zapomnieniu w archiwach Drugiej Międzynarodówki. Zdaniem Dunajewskiej Lenin interpretował więc Heglowską ideę Absolutu w sposób zbyt materialistyczny, chwytając się tego, że Hegel w ostatnich fragmentach ostatniego rozdziału Nanki logiki pisze o przejściu od logiki do natury. Dla Lenina Hegel w tym miejscu „wyciąga rękę w stronę materializmu” (Lenin 1988a, 197). Jednak, jak wyjaśniała Dunajewska, Lenin zignorował jednocześnie to, co następowało w sąsiednich fragmentach, a więc kolejne przejście - tym razem od logiki do ducha czy myśli [Geist].

Po czwarte wreszcie, Dunajewska podnosiła, że chociaż niewattpliwym osiagnięciem Lenina była dialektyczna reinterpretacja globalnej polityki, zbudowana na sprzeczności między imperializmem i narodowym wyzwoleniem, to jednocześnie nie zdołał on poddać równie dialektycznej reinterpretacji elitarystycznej koncepcji partii awangardowej, która choć zmodyfikowana pod naciskiem spontanicznej, oddolnej rewolucyjnej kreatywności pozostała jednak zasadniczo niezmieniona od czasów Co robić? Zwracała wobec tego uwagę 
na konieczność stworzenia nowej koncepcji organizacyjnej, zakorzenionej w tym, co określała jako dialektykę organizacji i filozofii (zob. Dunayevskaya 2002). Mogłaby ona być ugruntowana nie tylko w dziele Hegla, lecz również obszernych, choć nieco zapominanych tekstach Marksa dotyczących działalności organizacyjnej, poczynając od Ligi Komunistów, poprzez I Międzynarodówkę, a na Krytyce Programu Gotajskiego skończywszy.

\section{Wnioski}

Pod wszystkimi tymi względami zmagania Lenina z myślą Hegla przypadające na lata 19141915 i wyrastające $z$ nich problemy zajmują ważne miejsce w spuściźnie marksizmu. Ignorowanie ich jest równoznaczne $z$ odrzuceniem części bogactwa, które tkwi w tej tradycji. Fakt, że rosyjska rewolucja pod rządami Stalina i jego następców uległa transformacji i zmieniła się w swe własne przeciwieństwo - totalitarne społeczeństwo kapitalizmu państwowego - tym bardziej powinno skłaniać do uczciwego stawienia czoła sprzecznej naturze dwudziestowiecznego marksizmu i jego historii. Dlatego też wszelkie próby powrotu do Marksa bez jednoczesnego porachowania się z Leninem i spuścizną jego generacji, maja istotne ograniczenia. Dotyczy to nawet najlepiej znanej spośród ostatnich prób odzyskania Marksa dla teraźniejszości, czyli Widm Marksa Jacques’a Derridy.

Zarysowałem tu trzy najważniejsze osiagnięcia Lenina w kwestii dialektyki i walk narodowowyzwoleńczych. Po pierwsze, podniósł on kwestię przyjęcia właściwej dialektyki jako podstawy dla rewolucyjnego marksizmu i w opozycji do marksizmu reformistycznego, torując tym samym drogę takim autorom jak choćby Lukács. Po drugie, jego dialektyczna analiza imperializmu i walk narodowowyzwoleńczych przewidująco wykazała znaczenie antyimperialistycznych ruchów zarówno w dwudziestym wieku, jak i w obecnym stuleciu. Poszerzając ortodoksyjnie marksistowskie rozumienie rewolucyjnego podmiotu, Lenin niejako torował też drogę kolejnym tego rodzaju próbom prowadzącym do pozyskania dowspólnej walki już nie tylko narodowych i etnicznych ruchów wyzwoleńczych (jak postulował to sam Lenin), ale również ruchów kobiecych, ekologicznych, gejowskich i lesbijskich oraz młodzieżowych. W przeciwieństwie jednak do współczesnych koncepcji polityki tożsamości Lenin zwraca naszą uwagę na rodzaj dialektycznej jedności tych różnych partykularnych form oporu. Po trzecie wreszcie, jego pisma na temat Hegla i dialektyki miały bezpośredni wpływ na rozwój wielu twórczych nurtów w obrębie heglowskiego marksizmu, zwłaszcza we Francji i Stanach Zjednoczonych.

Wszystko to pokazuje nie tylko znaczenie, jakie miało ponowne odkrycie przez Lenina dialektyki, lecz również nieodzowność dialektyki dla wszelkiej myśli i praktyki rewolucyjnej. Ignorując to dziedzictwo, działamy na własne ryzyko. Wciąż bowiem istnieje potrzeba jego krytycznego przyswojenia, jeśli mamy uniknąć błędów i pomyłek poprzedniego 
stulecia, które doprowadziły w marksizmie i myśli radykalnej do jeszcze głębszego kryzysu niż ten, z którym musiał się zmierzyć Lenin w 1914 roku.

Chciałbym z̧ożyć w tym miejscu podziekowania Shannon Linehan, Heinzowi Osterle i Albertowi Resisowi za syczliwe uwagi poczynione po lekturze pierwotnej wersji tego eseju.

Przetosiyt Kamil Piskata 


\section{Wykaz literatury}

Afary, Janet. 1996. The Iranian Constitutional Revolution, 1906-11: Grassroots Democracy, Social Democracy, and the Origins of Feminism. New York: Columbia University Press.

Althusser, Louis 1971. „Lenin before Hegel.” W Louis Althusser, Lenin and Pbilosophy, and Other Essays. Tłum. Ben Brewster. New York: Monthly Review.

Althusser, Louis 2009. W imieMarksa. Tłum. Michał Herer. Warszawa: Wydawnictwo Krytyki Politycznej.

Anderson, Kevin B. 1987. „Lenin, Bukharin, and the Marxian Concepts of Dialectic and Imperialism: A Study in Contrasts.” Journal of Political and Military Sociology 15.1: 197-212.

Anderson, Kevin B. 1995. Lenin, Hegel, and Western Marxism: A Critical Study. Urbana: University of Illinois Press.

Anderson, Kevin B. 2002. „A Recently Discovered Article by Erich Fromm on Trotsky and the Russian Revolution." Science and Society 66.2 (summer 2002): 266-73.

Bloch, Ernst. 1962. Subjekt-Objekt: Erläuterungenzu Hegel. Frankfurt: SuhrkampVerlag.

Burkhard, Fred Bud. 1999. French Marxism between the Wars: Henri Lefebure and the "Philosophies". Amherst: Prometheus Books.

Cliff, Tony. 1975. Lenin, vol. 1: Building the Party. London: Pluto Press.

Cliff, Tony. 1976. Lenin, vol. 2: All Power to the Soviets. London: Pluto Press.

Cliff, Tony. 1978. Lenin, vol. 3: The Revolution Besieged, 1917-1923. London: Pluto Press.

Cliff, Tony. 1979. Lenin, vol. 4: The Bolsheviks and World Communism. London: Pluto Press.

Dunayevskaya, Raya. 1958. Marxism and Freedom: From 1776 until Today. New York: Bookman.

Dunayevskaya, Raya. 1963. American Civilization on Trial. Detroit: News and Letters.

Dunayevskaya, Raya. 1973a. „Hegelian Leninism.” W Towards a New Marxism, red. Bart GrahliPaul Piccone. New York: Bookman.

Dunayevskaya, Raya. 1973b. Philosophy and Revolution: From Hegel to Sartre and from Marx to Mao. New York: Delacorte.

Dunayevskaya, Raya. 1984. Nationalism, Communism, Marxist Humanism, and the Afro-Asian Revolutions. Chicago: News and Letters.

Dunayevskaya, Raya. 1991. Rosa Luxemburg, Women's Liberation, and Marx's Philosophy of Revolution. Urbana: University of Illinois Press.

Dunayevskaya, Raya. 2002. The Power of Negativity: Selected Writings on the Dialectic in Hegeland Marx, red. Peter Hudisi Kevin B. Anderson. Lanham: Lexington Books.

Dupré, Louis. 1983. Marx's Social Critique of Culture. New Haven: Yale University Press.

Dutschke, Rudi. 1974. Versuch, Lenin auf die FüssezuStellen. Berlin: Verlag Klaus Wagenbach.

Elliott, Gregory. 1987. Althusser: The Detour of Theory. London: Verso.

Engels, Fryderyk. 1969. „Ludwik Feuerbach i zmierzch klasycznej filozofii niemieckiej.”

W Karol Marks i Fryderyk Engels, Drieła, t. 21. Warszawa: Książka i Wiedza.

Farber, Samuel. 1990. Before Stalinism: The Rise and Fall of Soviet Democracy. New York: Verso,

Fetscher, Iring. 1971. „The Relationship of Marxism to Hegel.” W IringFetscher, Marx and Marxism. Tłum. John Hargreaves. New York: Herder and Herder.

Fourth Congress of the Communist International. 1924. Abridged Report of Meetings Held at Petrograd and Moscow, Nov. 7-Dec. 3 1924.London: Communist Party of Great Britain.

Harding, Neil. 1978. Lenin's Political Thought, vol. 1. New York: St. Martin's.

Harding, Neil. 1981. Lenin's Political Thought, vol. 2. New York: St. Martin's.

Harding, Neil. 1996. Leninism. Durham: Duke University Press.

Hudis, Peter, Christopher A. Ford, Dave Black, Htun Lin i Kevin Anderson. 1996. BosniaHerzegovina: Achilles Heel of "Western" Civilization. Chicago: News and Letters. 
Hudis, Peter, Christopher A. Ford, Dave Black, Htun Lin i Kevin Anderson. 2000. Kosova: Writings from News and Letters, 1998-1999. Chicago: News and Letters.

James, C.L.R. 1977. Nkrumah and the Ghana Revolution. London: Allison and Busby.

James, C.L.R. 1980. Notes on Dialectics: Hegel-Marx-Lenin. Westport: Lawrence Hill.

Kołakowski, Leszek. 2009. Gtówne nurty marksizmu, t. 2. Warszawa: PWN.

Korsch, Karl. 2005. Marksizm $i$ filozofia. Tłum. Aleksander Ochocki. http://www.filozofia.uw.edu.pl//skfm/publikacje/korsch02.pdf.

Landy, Joanne. „Self-Determination and Diplomacy.” New Politics 27 (summer 1999): 27-33.

Lefebvre, Henri. 1959. La Somme et la reste.Paris: La Nef.

Lenin, Włodzimierz. 1984. „Materializm a empiriokrytycyzm.” W Włodzimierz Lenin, Džieła wssystkie, t. 18. Warszawa: Książka i Wiedza.

Lenin, Włodzimierz. 1987a. „Wyniki dyskusji o samookreśleniu.” W Włodzimierz Lenin, Dzieła wszystkie, t. 30. Warszawa: Książka i Wiedza.

Lenin, Włodzimierz 1987b. „O karykaturze marksizmu i o 'imperialistycznym ekonomizmie’.” W Włodzimierz Lenin, Drieła wszystkie, t. 30. Warszawa: Książka i Wiedza

Lenin, Włodzimierz. 1988a. „Zeszyty filozoficzne.” W Włodzimierz Lenin, Drieła wszystkie, t. 29. Warszawa: Książka i Wiedza.

Lenin, Włodzimierz 1988b. „Pierwotny szkic tez w kwestii narodowej i kolonialnej.” W Włodzimierz Lenin, Drieła wszystkie, t. 41, Warszawa: Książka i Wiedza.

Lenin, Włodzimierz. 1989a, „O znaczeniu wojującego materializmu.” W Włodzimierz Lenin, Dzieła wszystkie, t. 47. Warszawa: Książka i Wiedza.

Lenin, Włodzimierz 1989b. „O naszej rewolucji (W związku z notatkami N. Suchanowa).” W Włodzimierz Lenin, Drieła wszystkie, t. 47, Warszawa: Książka i Wiedza.

Liebman, Marcel. 1975. Leninism under Lenin. Tłum. Brian Pearce. London: Jonathan Cape.

Löwy, Michael. 1973. Dialectique et révolution. Paris: Éditions Anthropos.

Lukács, György. 1988. Historia i świadomość klasowa. Tłum. Marek Siemek. Warszawa: PWN.

Marcuse, Herbert. 1958. Soviet Marxism. New York: Columbia University Press.

Marcuse, Herbert. 1966. Rozum i rewolucja: Hegel a powstanie teorii społecznej. Tłum. Danuta Petsch. Warszawa: Książka i Wiedza.

Marks, Karol. 1951. Kapitał: Krytyka ekonomii politycznej, t. 1. Warszawa: Książka i Wiedza.

Marks,Karol. 1976. „Rękopisy ekonomiczno-filozoficzne z 1844 r.” W Karol Marks i Fryderyk Engels, Driela, t. 1. Warszawa: Książka i Wiedza.

McKay, Claude. 1979. The Negroes in America. Tłum. Robert J. Winter. Port Washington: Kennikat Press.

Merleau-Ponty, Maurice. 1973. Adventures of the Dialectic.Tłum. Joseph Bien. Evanston, Ill.: Northwestern University Press.

Negt, Oskar (red.). 1969. Kontroversenüberdialektischen und mechanistischenMaterialismus. Frankfurt: SuhrkampVerlag.

Nietzsche, Friedrich. 2003. „Schopenhauer jakowychowawca.” W Friedrich Nietzsche, Niewsęesnerozważania. Tłum. Leopold Staff. Kraków: Wydawnictwo Zielona Sowa.

Rabehl, Bernd. 1973. Marx und Lenin. Frankfurt: Verlagfür das Studium der Arbeiterbewegung.

Radek, Karl. 1984. „Their Song Is Played Out.” W Lenin's Struggle for a Revolutionary International, red. John Riddell. New York: Monad Press.

Riddell, John (red.). 1991. Workers of the World and Oppressed Peoples Unite! Proceedings and Documents of the Second Congress, 1920. New York: Pathfinder Press.

Riddell, John (red.). 1993. To See the Dawn: Baku, 1920_First Congress of the Peoples of the East. New York: Pathfinder Press. 
Service, Robert. 1985. Lenin: A Political Life, t. 1. Bloomington: Indiana University Press.

Service, Robert. 1991. Lenin: A Political Life, t. 2. Bloomington: Indiana University Press.

Service, Robert. 1996. Lenin: A Political Life, t. 3. Bloomington: Indiana University Press.

Service, Robert. 2000. Lenin: A Biography. Cambridge, MA: Harvard University Press.

Traverso, Enzo. 1994. The Marxists and the Jewish Question: The History of a Debate, 1843-1943. Tłum. Bernard Gibbons. Atlantic Highlands: Humanities Press International.

Trotsky, Leon. 1958. Trotsky's Diary in Exile. Cambridge: Harvard University Press.

Trotsky, Leon. 1967. Trotsky on Black Nationalism and Self-Determination. New York: Merit Publishers.

Trotsky, Leon. 1970. On the Jewish Question. New York: Pathfinder Press.

Trotsky, Leon. 1984. „Lessons of the Events, in Dublin.” W Lenin's Struggle for a Revolutionary International, red. John Riddell. New York: Monad Press. 
Kevin B. Anderson - profesor socjologii, nauk politycznych i studiów feministycznych na University of California. Wywodzi się z tradycji marksizmu dialektycznego i humanistycznego. Członek projektu Marx-Engels Gesamtausgabe. Autor m.in. Lenin, Hegel, and Western Marxism: A Critical Study (1995) i Marx at the Margins: On Nationalism, Ethnicity, and Non-Western Societies (2010).

\section{DANE ADRESOWE:}

Social Sciences \& Media Studies Bldg.

University of California

Santa Barbara, CA

93106-9430

EMAIL: kanderson@soc.ucsb.edu

CYTOWANIE: Anderson, Kevin B. 2016. Odkryta na nowo i uporczywie aktualna - o dialektyce w filozofii i polityce światowej. Praktyka Teoretyczna 2 (20). 83-111.

DOI:10.14746/prt.2016.2.3 